Maurice A. Deane School of Law at Hofstra University Scholarly Commons at Hofstra Law

Hofstra Law Faculty Scholarship

2012

\title{
Bridging the Gap: How Introducing Ethical Skills Exercises Will Enrich Learning in First Year Courses
}

Miriam R. Albert

Maurice A. Deane School of Law at Hofstra University

Jennifer A. Gundlach

Maurice A. Deane School of Law at Hofstra University

Follow this and additional works at: https://scholarlycommons.law.hofstra.edu/faculty_scholarship

\section{Recommended Citation}

Miriam R. Albert and Jennifer A. Gundlach, Bridging the Gap: How Introducing Ethical Skills Exercises Will Enrich Learning in First Year Courses, 5 Drexel L. Rev. 165 (2012-2013)

Available at: https://scholarlycommons.law.hofstra.edu/faculty_scholarship/394

This Article is brought to you for free and open access by Scholarly Commons at Hofstra Law. It has been accepted for inclusion in Hofstra Law Faculty Scholarship by an authorized administrator of Scholarly Commons at Hofstra Law. For more information, please contact lawcls@hofstra.edu. 


\title{
BRIDGING THE GAP: HOW INTRODUCING ETHICAL SKILLS EXERCISES WILL ENRICH LEARNING IN FIRST-YEAR COURSES
}

\author{
Miriam R. Albert ${ }^{*}$ \\ and \\ Jennifer A. Gundlach ${ }^{* *}$
}

\begin{abstract}
Law schools have begun to raise the bar beyond the baseline mandates and aspirational goals of MacCrate and Carnegie, and are looking seriously at how to implement the suggested methods of Best Practices and/or other innovative models. Facing increasing pressure to prepare law students to be ethical, competent practitioners, law schools must rise to the challenge of introducing a broad range of practical skills and ethical values across the curriculum and throughout the students' three years of law school. It is no longer reasonable that a single required course in professional responsibility will somehow suffice to instill the long-lasting and deep values in legal ethics expected by the members of our profession, clients, and the American public. Instead, law schools are introducing more experiential opportunities throughout the curriculum that offer students the opportunity to integrate and apply the range of skills and substantive law that they have learned.

These experiential opportunities seem to be unavailable during the first year of law studies entirely. This is a missed opportunity, since first-year courses are fertile ground for exposure to principles of professional responsibility because it is in this time period that students begin learning foundational lawyering skills. First-year law faculty face unique challenges as they seek to orient law students to basic legal methods, analysis, and the concept of doctrinal law stemming from cases and statutes. Our own teach-

- Professor of Skills, Maurice A. Deane School of Law, Hofstra University; B.A., Tufts University; JD/MBA, Emory University; LLM, New York University School of Law. E-mail: miriam.r.albert@hofstra.edu. The Authors would like to thank the planning committees and participants at the Sixth Annual International Contracts Conference in February 2011 and at the Institute for Law Teaching and Learning Conference in June 2011 where we presented on this topic and received helpful feedback. In addition, we would like to acknowledge the valuable research support of Stephen Piraino.

* Senior Associate Dean for Academic Affairs and Clinical Professor of Law, Maurice A. Deane School of Law, Hofstra University; A.B., Kenyon College; JD, American University Washington College of Law. E-mail: Jennifer.gundlach@hofstra.edu.
\end{abstract}


ing experiences and research have shown that offering students the opportunity to apply doctrine in a practical context through simulated client interactions leads to a richer and more complete legal education, which we believe better prepares students for the ethical and competent practice of law. As part of these simulations, students are given a chance to experiment with foundational lawyering skills, such as client interviewing and counseling, problem solving, drafting, and synthesis of law and fact. While experimenting with these skills, students will also wrestle with the types of ethical dilemmas they will face in practice.

This Article, in large measure, is designed to introduce one such simulation, with academic and pedagogical support, to further the premise that introducing discussions of ethical layers in the first-year doctrinal courses will enhance both the students' understanding of such first-year courses and the students' own professional identities. These discussions may even inform and improve the professors' doctrinal teaching. We share one example of how a Contracts professor and a Lawyers' Ethics professor are responding to these challenges in a first-year classroom and offer theoretical and practical support for the notion that providing students with the opportunity to develop and/or hone essential lawyering skills through simulations within the context of a doctrinal class will better prepare students for the ethical and competent practice of law. By working together to share our expertise in doctrine, skills, and legal ethics, we believe that exercises like the one discussed in this Article help students learn the substance of the doctrinal subject explored at a deeper level. It also lays the groundwork for students to begin considering the ethical implications present as they analyze legal issues. Finally, students can begin to see how the application of doctrine necessarily involves a range of lawyering skills, and not just a discrete application of one area of law or one skill.

This Article offers support for the integration of ethical considerations into the first year of law school, generally focusing on the ABA Standards for Law School Accreditation and the Carnegie Report as forces driving the need for opportunities for first-year law students to consider ethics in context. The result is a greater understanding of the relevant pedagogy and a catalyst for creating opportunities to develop students' professional identities. We examine the learning objectives sought to be satisfied through the integration of ethics and contracts and provide a description of this problem-centered exercise usable in any first-year Contracts class, with the fact pattern and other supporting documentation necessary to run the simulation attached as Appendices. The Article concludes with anecdotal results from the Authors' use of this exercise and suggestions for assessment tools for faculty to use in evaluating the exercise. 


\section{TABLE OF CONTENTS}

INTRODUCTION 168

I. WHY INTEGRATE PROFESSIONAL RESPONSIBILITY AND

LAWYERING SKILLS INTO A FIRST-YEAR DOCTRINAL

CLASS?

A. The ABA Standards for Law School Accreditation Require a Baseline of "Substantial Instruction" in Professional Responsibility and Lawyering Skills.

B. Other Outside Forces Are Placing Increased Pressure on Law Schools to Do More to Integrate the Teaching of Skills and Professional Responsibility Throughout the Curriculum

C. Law Schools' Recent Efforts to Engage Students in Multiple Opportunities for Learning Skills and Professional Responsibility Across the Curriculum Is Raising the Bar

D. Law Schools Must Do More to Infuse Opportunities for the Development of Students' Professional Identities

E. A First-Year Contracts Class Offers Unique Opportunities for Introducing Professional Responsibility and Lawyering Skills

II. BROADENING THE SCOPE OF LEARNING OBJECTIVES FOR

FIRST-YEAR COURSES AND ENSURING ACHIEVEMENT OF

THOSE OBJECTIVES: AN ILLUSTRATION.

A. Identification of Learning Objectives for a First-Year

B. How We Seek to Meet These Objectives Through Use of a Simulated Exercise in First-Year Contracts

III. THE SIMULATION..................................................................194

A. Overview of the Exercise.................................................194

B. Benefits of the Exercise .................................................196

CONCLUSION: MEASURES OF SUCCESS AND NEXT STEPS ...............197

APPENDIX A: INSTRUCTION MEMORANDUM FROM FACULTY

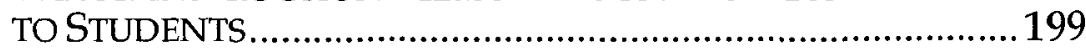

APPENDIX B: ASSIGNMENT MEMORANDUM TO BE DISTRIBUTED TO STUDENTS 200

APPENDIX C: ADDITIONAL FACTS FOR CLIENT "LACY

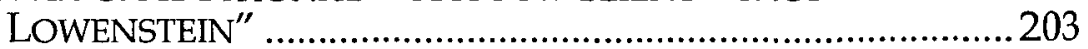

APPENDIX D: DISCUSSION POINTS FOR PLENARY SESSION ............204 


\section{INTRODUCTION}

Public mistrust of lawyers likely goes back at least to the days of Lincoln, ${ }^{1}$ and, for just as long, lawyers have worked to earn the public's trust. For more than a century, the legal profession in America has recognized the importance of codified standards of professional responsibility. In 1908, the American Bar Association (ABA) included in the preamble to the first Canons of Professional Ethics the goal "that the public shall have absolute confidence in the integrity and impartiality" of the administration of justice and in "the conduct and the motives of the members of our profession." ${ }^{2}$ Even today, the preamble to the Model Rules of Professional Conduct notes lawyers' "special responsibility for the quality of justice" and emphasizes that lawyers must resolve ethical dilemmas "through the exercise of sensitive professional and moral judgment guided by the basic principles underlying the Rules." ${ }^{3}$ The ABA Section of Legal Education similarly views "ethical conduct and integrity" as an "[e]ssential characteristic of the professional lawyer." ${ }^{\prime 4}$

Despite these directives and the existence of strict standards of professional responsibility for lawyers in every U.S. jurisdiction, there are numerous examples of lawyers engaging in unethical behavior, contributing to public mistrust and dissatisfaction with the legal profession. In fact, despite the increased attention on legal ethics and professionalism by the bench, the bar, and legal educators, the overwhelming consensus of the public seems to be that lawyers' ethics are declining. ${ }^{5}$ Polls from the past several decades indicate that our society's esteem for the legal profession continues to

1. 2 Abraham LinCOLN, Notes for a Law Lecture, in THE COllected WORKS OF AbRAHAM LINCOLN 81, 82 (Roy P. Basler ed., 1953) ("There is a vague popular belief that lawyers are necessarily dishonest. I say vague, because when we consider to what extent confidence and honors are reposed in and conferred upon lawyers by the people, it appears improbable that their impression of dishonesty is very distinct and vivid. Yet the impression is common, almost universal. Let no young man choosing the law for a calling for a moment yield to the popular belief - resolve to be honest at all events; and if in your own judgment you cannot be an honest lawyer, resolve to be honest without being a lawyer. Choose some other occupation, rather than one in the choosing of which you do, in advance, consent to be a knave.").

2. CANONS OF ETHICS pmbl. (1908).

3. MOdel Rules of Prof'l CONDUCT pmbl. (2011).

4. AM. BAR ASS'N SECTION ON LEGAL EDUC. AND AdMISSIONS TO THE BAR, TEACHING AND Learning Professionalism, Report of THE Professionalism CoMmittee 7 (1996) [hereinafter TEACHING AND LEARNING PROFESSIONALISM].

5. See Russell G. Pearce, The Professionalism Paradigm Shift: Why Disregarding Professional Ideology Will Improve the Conduct and Reputation of the Bar, 70 N.Y.U. L. REV. 1229, 1256 (1995) (citations omitted); Russell G. Pearce, Teaching Ethics Seriously: Legal Ethics as the Most Important Subject in Law School, 29 LOY. U. CHI. L.J. 719, 728 (1998) [hereinafter Teaching Ethics]. 
plummet. ${ }^{6}$ More recently, a 2010 Gallup Poll found that only $17 \%$ of a random sample of over 1,000 Americans surveyed would rate the honesty and ethical standards of lawyers as "high" or "very high," garnering considerably lower ratings than doctors (66\%) and even bankers $(23 \%)^{7}$ which, in light of the "Occupy Wall Street" movement, is disturbing to say the least.

Similarly, a survey in 2002 by the ABA Section of Litigation found that $69 \%$ of those polled agreed that lawyers are "more interested in making money than in serving their clients," and 57\% believed that most lawyers are "more concerned with their own self-promotion than their clients' best interests." ${ }^{\prime 8}$ In essence, the public describes lawyers as "greedy, manipulative and corrupt." ${ }^{\prime \prime}$ This perception by the public (some percentage of whom are presumably clients), as well as a continuing array of pubic examples of unethical lawyering, has placed mounting pressure on law schools to produce graduates who have had more comprehensive and context-based training in ethics and professional responsibility. ${ }^{10}$ With this increasing pressure on law schools to prepare students to be ethical, competent practitioners, law schools must rise to the challenge of introducing a broad range of practical skills and ethical values across the curriculum and throughout the three years of law school. It is no longer reasonable that a single, required course in professional responsibility will somehow suffice to instill the long-lasting and deep values in legal ethics expected by both the members of our profession, clients, and the American public. Instead, law schools have begun to experiment with a range of options to infuse the teaching and learning of professional responsibility and ethical considerations throughout the curriculum. Yet, our research has not uncovered even one class solely focused on ethics in the first year curriculum of

6. See, e.g., Gary A. Hengstler, Vox Populi: The Public Perception of Lawyers: ABA Poll, 79 A.B.A. J. 60,62 (1993) (finding that only $22 \%$ of the public views lawyers as "honest and ethical"); Chris Klein, Poll: Lawyers Not Liked, NAT'L L. J., Aug. 25, 1997, at 1 (noting that the percentage of the public who view the legal profession as one "of very great prestige" dropped from $36 \%$ in 1977 to $19 \%$ in 1997); David W. Moore, Nurses Top List in Honesty and Ethics Poll, GALLUP (Dec. 7, 2004), http://www.gallup.com/poll/14236/nurses-top-list-honesty-ethicspoll.aspx.

7. See Jeffrey M. Jones, Nurses Top Honesty and Ethics List for $11^{\text {th }}$ Year, GalluP (Dec. 3, 2010), http://www.gallup.com/poll/145043/Nurses-Top-Honesty-Ethics-List-11-Year.aspx. This represents a marginal change in the past several years of the survey. $I d$.

8. Id. (citing ABA SEction of Litigation, Public PERCEPTIONS OF LAWYERS Consumer ReSEARCH FINDINGS 7 (A pr. 2002), http://www.cliffordlaw.com/abaillinoisstatedelegate/ publicperceptions1.pdf).

9. Id.

10. See Teaching and Learning Professionalism, supra note 4, at 13-25. 
an ABA-accredited school. ${ }^{11}$ And our sense is, albeit it anecdotal in basis, that little or no discussion of ethical issues occurs in most firstyear classrooms nationwide.

We believe this is a missed opportunity and that all first-year courses are fertile ground for exposure to principles of professional responsibility because students learn foundational lawyering skills in this time period. First-year law faculty face unique challenges as they seek to orient law students to basic legal methods, analysis, and the concepts of doctrinal law embedded in cases and statutes. Our own teaching experiences and research show that offering students the opportunity to apply doctrine in a practical context through simulated client interactions leads to a richer and more complete legal education. As part of these simulations, students experiment with foundational lawyering skills, such as client interviewing and counseling, problem-solving, drafting, and synthesis of law and fact. While experimenting with these skills, students will also wrestle with the types of ethical dilemmas they will face in practice, which better prepares students for the ethical and competent practice of law.

This Article introduces one such simulation, with academic and pedagogical support, to further the premise that introducing discussions of the ethical layers in the first-year doctrinal courses will enhance both the students' understanding of those courses and the

11. A number of schools have begun to introduce professional responsibility and lawyering skills concepts into the first-year curriculum, but few have made the bolder step of doing so within the doctrinal offerings. Washington and Lee University School of Law includes Professional Responsibility as a first-year, three-credit offering. See First Year Course Descriptions, W\&L L. SCH., http://law.wlu.edu/academics/page.asp?pageid=1100 (last visited Sept. 21, 2012). The University of Dayton School of Law offers a full-year Legal Profession course in the first year. See Course Descriptions, U. OF DAYTON, http://www.udayton.edu/law/ registrar/course_descriptions.php (last visited Sept. 21, 2012). The University of Denver Sturm College of Law includes a comprehensive Lawyering Process program that integrates skills and professional responsibility into the first-year curriculum. See Lawyering rocess, STURM C. OF L., http://www.law.du.edu/index.php/lawyering-process (last visited Sept. 21, 2012). We note that Professor Michael Hunter Schwartz at Washburn University School of Law is one example of a faculty member who integrates lawyering skills and professional responsibility into a first-year Contracts course. For more information about his course, see Michael Hunter Schwartz, Contracts I and II, EDUCATING TOMORROW'S LAW., http:/ / educatingtomorrowslawyers.du.edu/course-portfolios/detail/michael-hunterschwartz (last visited Oct. 22, 2012). Professor Gillian K. Hadfield at the University of Southern California Gould School of Law employs a similar model in her first-year Contracts course. For more information about her course, see Gillian K. Hadfield, First Year Contracts, EDUCATING TOMORROW'S LAW., http://educatingtomorrowslawyers.du.edu/ course-portfolios/detail/contracts-first-year (last visited Oct. 22, 2012). 
students' own professional identities and may even inform and improve the professors' doctrinal teaching.

Law school pedagogy is evolving and legal educators continue to learn more about what our students need to prepare them for the practice of law, as well as how best to deliver it. Our anecdotal sense is that much of the emphasis of curricular and teaching innovation has focused on upper-level courses. If true, this emphasis denies first-year faculty the opportunity to collaborate with each other to build a foundation of competency in the substantive knowledge of doctrinal rules, lawyering skills, and ethical practice.

This Article aims to share one approach to how a Contracts professor and a Lawyers' Ethics professor are responding to these challenges in a first-year classroom. We will offer theoretical and practical support for the notion that providing students with the opportunity to develop and/or hone essential lawyering skills through simulations within the context of a doctrinal class will better prepare our students for the ethical and competent practice of law. By working together to share our expertise in doctrine, skills, and legal ethics, we believe that exercises like the one discussed herein help our students learn the substance of the doctrinal subject explored at a deeper level. The exercise also lays the groundwork for students to begin consideration of the ethical implications present as they analyze legal issues. Finally, students can begin to see how the application of doctrine necessarily involves a range of lawyering skills, and not just a discrete application of one isolated area of law or one particular skill.

Part I of the Article offers support for the integration of ethical considerations into the first year of law school generally, focusing on the ABA Standards for Law School Accreditation (ABA Standards) and the Carnegie Report as forces that drive the need for opportunities for first-year law students to consider ethics in context, which result in greater understanding of the relevant pedagogy and create opportunities for development of students' professional identities. This Part focuses on first-year Contracts as a test subject for our approach, examining the viability and advisability of integrating ethical considerations traditionally not broached until upper level courses into the study of Contracts, a course that is required in most, if not all, ABA-accredited law school curricula in the first year of study. Part II discusses our intent to broaden the scope of learning objectives that are traditionally considered in first-year doctrinal courses, and provides a description of the additional educational goals that we have for our students and how we seek to achieve 
those goals. Part III provides a description of this problem-centered exercise usable in any first-year Contracts class, with the fact pattern and other supporting documentation necessary to run the simulation attached as Appendices. ${ }^{12}$ This Part also offers an analysis of the benefits of such an exercise for students, and explores the benefits for faculty. Part IV concludes with anecdotal results from the Authors' use of this exercise, and offers suggested assessment tools for faculty to use in evaluating the exercise.

\section{WHY INTEGRATE PROFESSIONAL RESPONSIBILITY AND LAWYERING SKILLS INTO A FIRST-YEAR DOCTRINAL CLASS?}

\section{A. The ABA Standards for Law School Accreditation Require a Baseline of "Substantial Instruction" in Professional Responsibility and Lawyering Skills}

To put our proposed exercise in its proper pedagogical context, an examination of the relevant ABA Standards, which provide a baseline requirement for professional responsibility and skills instruction in law schools, is warranted. As the primary accrediting body for law schools in the United States, the ABA continues to play an important role in shaping the essential elements of the academic program in legal education. For many years, the ABA has required accredited law schools to provide instruction in professional responsibility and professional skills, but with little or no guidance on how to accomplish such instruction. ${ }^{13}$ In addition, no mention is made about the importance of shaping students' professional identity within the context of learning such skills and ethical standards.

12. The simulation materials to be given to the students are set out in Appendices $A$ and $B$. Additional facts for the person playing the role of the client in the simulation are in Appendix C. Discussion points for faculty are in Appendix D.

13. From 1921 to 1973, the ABA's Standards for Legal Education included no mandate that law schools require instruction in legal ethics or professional responsibility. See Laurel S. Terry, A Survey of Legal Ethics Education in Law Schools, in ETHICS IN ACADEMIA 61, 65-66 (S.K. Majumdar et al. eds., 2000). The majority of law schools, however, have offered some course instruction in ethics as early as the 1930s. Id.; J.P. Ogilvy, Celebrating CLEPR's 40th Anniversary: The Early Development of Clinical Legal Education and Legal Ethics Instruction in U.S. Law Schools, 16 CLINICAL L. REV. 1, 6 \& n.23 (2009) (citations omitted). In 1974, the ABA amended its accreditation standards, and, under the new Standards for Approval of Law Schools, law schools were required to offer instruction in legal ethics. Though, the ABA gave schools discretion as to whether to offer a specific course in legal ethics or to instead follow the "pervasive" method whereby ethics were infused throughout the curriculum. Terry, supra note 13, at 65-66; see also William Barrett, Law Schools Stress Ethics, N.Y. TimES, Sept. 22, 1974, at 69 (reporting on the new ABA mandate regarding ethics instruction in law schools). 
In 1980, partially due to the $\mathrm{ABA}^{\prime}$ 's efforts to require instruction in professional responsibility, the National Conference of Bar Examiners began administering the Multistate Professional Responsibility Examination (MPRE), a two-hour multiple-choice exam on the ABA's Model Rules of Professional Conduct. ${ }^{14}$ As of 2010, fifty-two jurisdictions now require a passing MPRE score as a prerequisite for bar admission..$^{15}$ A discussion of any predictive value or even any link between instruction in professional responsibility in law school and one's success on the MPRE and the ultimate ethical nature of one's legal practice is well beyond the scope of this Article. ${ }^{16}$ That said, law schools have tended to focus the instruction in required professional responsibility courses on covering the black-letter law of the Model Rules of Professional Conduct and students tend to view these courses as MPRE-prep courses. ${ }^{17}$

The latest version of the ABA Standards still lacks guidance on how to implement the required content of the academic program, but has slightly raised the bar for this required instruction. ABA Standard 301(a) generally states that each accredited law school "shall maintain an educational program that prepares its students for ... effective and responsible participation in the legal profession." ${ }^{\prime 18}$ In 2005, the ABA's Section on Legal Education and Admissions to the Bar, responding in part to the MacCrate Report, discussed infra, again revised the accreditation standards to require law schools to offer students "substantial" instruction in "legal analysis and reasoning, legal research, problem solving, and oral communi-

14. George T. Barrow, Letter from the Chairman, 49 B. EXAMINER 43, 44 (1980).

15. As of 2010, Washington, Wisconsin, Maryland, and Puerto Rico do not use the MPRE; the remaining fifty states, as well as the District of Columbia, Guam, the Northern Mariana Islands, and the Virgin Islands use the exam. See MPRE Jurisdictions, NATIONAL CONFERENCE OF BAR EXAMINERS, http://www.ncbex.org/multistate-tests/mpre/whichjurisdictions-administer-the-mpre/ (last visited Sept. 21, 2012).

16. While bar examiners continue to defend the merits of this uniform test, many members of the bar and the academy have been highly critical of its value. See Paul T. Hayden, Putting Ethics to the (National Standardized) Test: Tracing the Origins of the MPRE, 71 FORDHAM L. REV. 1299,1300 (2003) (discussing negative views of the exam).

17. See TEACHING AND LEARNING PROFESSIONALISM, supra note 4, at 40-41 (reporting a 1994 survey finding that $44 \%$ of schools offer a required two-credit course with $6 \%$ requiring no course at all, $23 \%$ requiring a three-credit course, and the remainder having a variety of approaches, including a one-credit required course as well as more challenging options); Deborah L. Rhode, Ethics by the Pervasive Method, 42 J. LEGAL EDUC. 31, 39 \& n.43 (1992) (discussing informal survey of ethics teaching at leading law schools, finding that "slightly over half" of the ninety-two schools reporting a mandatory ethics course offered a two-credit course).

18. ABA STANDARdS AND RUles OF PROCEDURE FOR APPROVAl OF LAW SCHS., Standard 301(a) (2012-2013). 
cation."19 It also required other "professional skills generally regarded as necessary for effective and responsible participation in the legal profession," including "live-client or other real-life practical experiences," as well as the "history, goals, structure, values, rules and responsibilities of the legal profession and its members," including instruction in the law of lawyering and the ABA's Model Rules of Professional Conduct. ${ }^{20}$ The revised language represented an effort to respond to increasing demands for further instruction in skills, ethics, and professional responsibility in law school. ${ }^{21}$ Again, however, the ABA continues to provide little or no guidance on how law schools should accomplish such instruction and ignores the broader realm of professionalism and ethical instruction so critical for practice, instead opting for general language that encourages law schools to be "creative" in developing programs of instruction. ${ }^{22}$

Arguably, one required course in professional responsibility or one "skills" course is insufficient to meet the ABA Standards, although that seems to be the trend nationwide. ${ }^{23}$ Any professor who teaches a required ethics course will likely confirm that it is difficult, if not impossible, to cover all of the Model Rules of Professional Responsibility in two or three credits, much less delve into the broader realm of legal ethics and reflective professional judgment and/or the doctrinal law of legal malpractice and fiduciary relations. Yet

19. Id. at Standard 302(a).

20. Id at Standard 302(a)-(b)(1), Interpretation 302-9.

21. Most notably, the MacCrate Report called for greater instruction in legal ethics and professional responsibility. See AM. BAR ASS'N SECTION ON LEGAL EDUC. AND ADMISSIONS TO THE BAR, LEGAL EDUCATION AND PROFESSIONAL DEVELOPMENT - AN EDUCATIONAL CONTINUUM, REPORT OF THE TASK FORCE ON LAW SCHOOLS AND THE PROFESSION: NARROWING THE GAP 203-07 (1992) [hereinafter THE MACCRATE REPORT].

22. See ABA STANDARdS \& RULES OF PROCEDURE FOR APPROVAL OF LAW SCHS., Interpretation 302-2 (2012-2013). However, it does provide a list of professional skills that are "among the areas of instruction ... that fulfill Standard 302(a)(4)," including trial and appellate advocacy, alternative methods of dispute resolution, counseling, interviewing, negotiating, problem solving factual investigation, organization and management of legal work, and drafting. Id.; see also id. at Standard 301(a) (requiring law school programs prepare students for the bar and for legal practice).

23. Based on a review of the top one hundred schools in the US News and World Report rankings from 2011, a majority of the schools require three credits of professional responsibility/ethics instruction, usually satisfied through a required course. Nineteen schools require two credits, again usually by requiring students to take a specific two-credit course. Approximately one quarter of the schools require only one course in professional responsibility/ethics, which can be fulfilled by enrolling in any one of several courses ranging from two to four credits. Michigan State University College of Law introduced a new requirement in 2011 whereby students are required to take a three-credit course in Professional Responsibility and an additional one-credit course on Lawyers and Ethics. 
many $\mathrm{ABA}$-accredited law schools require just that one or twocredit course.

Relegating courses on professional responsibility and lawyering skills to just one or a few required courses marginalizes the critical significance of ethical values and standards, as well as the broad range of lawyering skills that are so critical in every lawyer's professional career. ${ }^{24}$ In addition, this curricular choice by law schools leaves students with the erroneous impression that ethics and "skills" are at best divorced from, and, at worst, irrelevant to, other doctrinal areas. ${ }^{25}$ As a result, students may dismiss ethics and lawyering skills as irrelevant to their doctrinal studies and to effective lawyering overall. ${ }^{26}$

It is not just law schools that view the MPRE as the true barometer of sufficient exposure to professional responsibility. State and national bar examiners continue to focus primarily on assessing graduates' knowledge of doctrinal law in the MPRE as well as in state and multistate bar exams. The narrow focus and testing methodology of the MPRE and the resulting emphasis on preparation for this test in basic professional responsibility courses contribute little to the development of ethics and professionalism for law students. ${ }^{27}$

24. Steven Friedland, A Critical Inquiry into the Traditional Use of Law School Evaluation, 23 PACE L. REV. 147, 182 (2002); Deborah L. Rhode, Professionalism in Professional Schools, 27 FLA. ST. U. L. REV. 193, 195 (2000).

25. See Deborah L. Rhode, Teaching Legal Ethics, 51 ST. LouIS U. L.J. 1043, 1051-52 (2007). "As long as law schools teach students to value effective legal arguments without regard to the moral and ethical consequences of their actions, they will not be motivated to value embedding ethical and moral considerations in their professional behavior as lawyers." Alan Lerner, Using our Brains: What Cognitive Science and Social Psychology Teach Us About Teaching Law Students To Make Ethical, Professionally Responsible Choices, 23 QUINNIPIAC L. REv. 643, 686 (2004).

26. See Friedland, supra note 24 , at 168 .

27. According to the National Conference of Bar Examiners:

The purpose of the MPRE is to measure the examinee's knowledge and understanding of established standards related to a lawyer's professional conduct; the MPRE is not a test to determine an individual's personal ethical values. Lawyers serve in many capacities: for example, as judges, advocates, counselors, and in other roles. The law governing the conduct of lawyers in these roles is applied in disciplinary and bar admission procedures, and by courts in dealing with issues of appearance, representation, privilege, disqualification, and contempt or other censure, and in lawsuits seeking to establish liability for malpractice and other civil or criminal wrongs committed by a lawyer while acting in a professional capacity.

The MPRE is based on the law governing the conduct of lawyers, including the disciplinary rules of professional conduct currently articulated in the American Bar Association (ABA) Model Rules of Professional Conduct, the ABA Model Code of Judicial Conduct (CJC), as well as controlling constitutional decisions and generally accepted principles established in leading federal and state cases and in procedural 
Similarly, many schools' curricula continue to emphasize core doctrinal subjects that are tested on the bar exam. Thus while the ABA Standards call for substantial instruction, they provide little incentive for law schools to invest in a curricular landscape that goes much beyond what is required and what will be assessed for admission to the bar. The unfortunate result is that it is still possible for an ABA-accredited law school to graduate students who have taken a required ethics course and a required skills class or two, yet have little or no exposure to the training needed for competent, ethical practice. ${ }^{28}$ It is our anecdotal sense that most lawyers experience discomfort and even considerable stress when they are uncertain about how best to proceed when facing an ethical dilemma or when they must perform a task that requires a set of skills for which they received little or no practice in law school. Law schools contribute to new graduates' anxiety when they fail to prepare them for those moments in practice when the doctrinal rules of law only get them so far.

Too much emphasis on black letter law, which, while important, predisposes students to focus too heavily on memorization of those rules for purposes of the final exam, the MPRE and ultimately the bar exam. For example, it does nothing to encourage students to delve into the broader ethical issues and policy considerations that underlie application of doctrinal rules. ${ }^{29}$ As Professor Deborah Rhode has noted, "[1]aw schools teach in subtexts as well as texts, and a faculty's member's pervasive silence about professional responsibility sends a clear and counterproductive message." ${ }^{30}$ Similarly, failure to provide students with opportunities to see how the application of doctrinal rules is but one of many lawyering skills that must be used in problem-solving produces one-dimensional learning. It is time to end the pervasive segregation of professional

and evidentiary rules.

MPRE, NAT'L CONF. OF BOARD EXAMINERS, http://www.ncbex.org/multistate-tests/mpre (last visited Oct. 21, 2012).

28. According to Professor Rhode, "[t]he conventional view on most faculties has been that education in professional responsibility is someone else's responsibility." Rhode, supra note 17, at 31. Similar views are often expressed about skills courses.

29. See, e.g., Celia R. Taylor, Teaching Ethics in Context: Wood v. Lucy, Lady Duff-Gordon in the First Year Curriculum, 28 PACE L. REv. 249, 250-52 (2008). As Professor Celia Taylor notes, "[e]thical concerns pervade every area of law, and as professors we are charged with teaching our students to recognize and resolve legal dilemmas and to help them gain a deeper appreciation for ethical standards and professional responsibility." Id. at 251.

30. Deborah L. Rhode, Into the Valley of Ethics: Professional Responsibility and Educational Reform, 58 L. \& CONTEMP. PROBS. 139, 145 (1995). 
responsibility and professional skills from the instruction of doctrinal law and instead seek out opportunities to provide exposure and practice to students early and often. Professor Russell Pearce has proposed that ethics is the most important subject in the curriculum and should "provide the lens through which students view what it means to be a lawyer and discover how to find meaning in their work." ${ }^{31}$ Exercises like the one discussed herein provide an opportunity to do just that.

Accordingly, the ABA Standards and the necessary focus on preparation for the MPRE and bar exams provide a baseline, but one that is insufficient for equipping law students with the array of professional skills they will need to competently represent their clients and effectively work their way through the ethical dilemmas they will inevitably face in practice. Moreover, the ABA Standards as currently structured do not sufficiently incentivize legal educators to focus enough attention on the cultivation of law studenits' professional responsibility and identity, nor the depth of professional skills they will need in practice.

\section{B. Other Outside Forces Are Placing Increased Pressure on Law Schools to Do More to Integrate the Teaching of Skills and Professional Responsibility Throughout the Curriculum}

While all ABA-accredited law schools must follow the ABA Standards for Law School Accreditation, most also choose to comply, to the extent possible, with recent recommendations to reform legal education by introducing and integrating more professional skills and opportunities to enhance students' understanding of their professional responsibilities into the curriculum.

In 1992, the ABA Section on Legal Education and Admission to the Bar issued the Report on Legal Education and Professional Development (commonly referred to as the MacCrate Report). ${ }^{32}$ The MacCrate Report contained a list of "fundamental lawyering skills" ${ }^{\prime 3}$ and "fundamental values of the profession" ${ }^{34}$ that should be

31. Russell G. Pearce, Legal Ethics Must Be the Heart of the Law School Curriculum, 26 J. LEGAL PROF. 159, 159 (2002).

32. THE MACCRATE REPORT, supra note 21.

33. The fundamental lawyering skills are: problem solving; legal analysis and reasoning; legal research; factual investigation; communication; counseling; negotiation; litigation and alternative dispute-resolution procedures; organization and management of legal work; and recognizing and resolving ethical dilemmas. Id. at 138-40.

34. The fundamental values of the profession are: provision of competent representation; 
introduced in law school, with the overriding goal to improve the preparation of lawyers for practice. ${ }^{35}$ It sought to provide law students with an "inventory of skills and values" that are "keyed to lawyers' work and professional activities." ${ }^{\prime 36}$ Translating this inventory of skills and values into an educational setting, according to the MacCrate Report, involves helping students understand lawyering tasks, providing opportunities to practice necessary skills, and offering the opportunity for reflection after professional critique. ${ }^{37}$ The report noted that many of these skills have been effectively taught through appellate case analysis, ${ }^{38}$ but more can and should be done in other areas to help students broaden their skill sets.

The MacCrate Report acknowledged that its primary goal was not to impose mandates, but to instead create a process through which "discussion in all sectors of the profession could be focused on questions about the nature of the skills and values that are central to the role and functioning of lawyers in practice. ${ }^{\prime \prime 9}$ It certainly served as a "lightning rod for discussion ... and critique" of legal education and the legal profession as a whole. ${ }^{40}$ While the report included a host of aspirational goals for the incorporation of doctrine, skills, and professional responsibility into the law school curriculum, there were no specific requirements or even clear suggestions for how to incorporate them, nor were there any mechanisms for reporting on law schools' efforts to do so. Therefore, these aspirational goals remained just that.

More recently, organizations beyond the ABA have picked up the call for reform in legal education. The Carnegie Foundation's Educating Lawyers: Preparation for the Profession of Law $w^{41}$ and the Clinical Legal Education Association's (CLEA) publication of Best Practices for Legal Education, ${ }^{42}$ both released in tandem in 2007 , have had profound influence not only on what should be taught, but how law

striving to promote justice, fairness and morality, striving to improve the profession; and professional self-development. Id. at 140-41.

35. Id. at 123 .

36. Id. at $242-43$.

37. Id. at 243 .

38. Id.

39. Id. at 124 .

40. Russell Engler, The MacCrate Report Turns 10: Assessing Its Impact and Identifying Gaps We Should Seek to Narrow, 8 CLINICAL L. REv. 109, 116 (2001).

41. William M. Sullivan ET al., Educating LaWyers: Preparation for the Profession OF LAW (2007) [hereinafter THE CARNEGIE RFPORT].

42. ROY StUCKey et al., BEST PRACTICES For LEGAL EduCATION: A VISION AND A ROAD MAP (2007). 
schools should teach students to better prepare them for practice. The Carnegie Report was a broader indictment of the traditional model of the Socratic case method as the primary vehicle of instruction in law schools and the failure of law schools to assess their students' learning; whereas, CLEA's primary goal was to offer a range of "best practices" in law school curriculum design and instruction.

A recent string of articles in The New York Times, The National Law Journal, The Chronicle of Higher Education, and other sources has drawn national attention to the issue of whether law schools are providing their students with sufficient preparation for practice. ${ }^{43}$ Likewise, legal employers are increasingly complaining about their young lawyers' lack of proficiency with the fundamental lawyering skills they need to succeed. ${ }^{44}$ As former Dean of New York Law School Richard Matasar wrote recently:

[L]egal employers catalogue a litany of shortcomings in law schools and their graduates: law students do not write effectively, do not understand the needs of their clients, do not have a sense of the economics of practice, do not understand the underlying businesses of clients, do not work well in teams, do not have sufficiently robust work ethics, and so on. ${ }^{45}$

Even law students recognize that, because of the recent economic downturn, legal employers expect new lawyers to have the ability to

43. See, e.g., David Segal, What They Don't Teach Law Students: Lawyering, N.Y. TIMES, Nov. 19, 2011, at A1, available at http://www.nytimes.com/2011/11/20/business/after-law-schoolassociates-learn-to-be-lawyers.html?_r=1; Alfred S. Konefsky \& Barry Sullivan, There's More to the Law Than "Practice Ready," THE CHRON. OF HIGHER EDUC. (Oct. 23, 2011), http://chronicle.com/article/Theres-More-to-the-Law-Than/129493/; Karen Sloan, Recent Grads Report Satisfaction with "Real World" Training in Law School, The NAT'L L. J. (Apr. 21, 2011), http://www.law.com/jsp/law/LawArticleFriendly.jsp?id=1202490927659; Karen Sloan, Law School? Who Needs It?, N.Y. L.J. (Dec. 6, 2011), http://www. newyorklawjournal.com/PubArticleNY.jsp?id=1202534608740\&slreturn=1; Debra Cassens Weiss, How Law Schools Can Produce 'Practice Ready' Grads: Operate Their Own Law Firms, A.B.A. J. (Aug. 18, 2011, 8:11 AM), http://www.abajournal.com/news/article/ how_law_schools_can_produce_practice_ready_grads_operate_their_own_law_firm/.

44. See, e.g., David E. Van Zandt, Northwestern University School of Law: Plan 2008 Executive Summary Findings and Recommendations, in PLI LAW FIRM LEADERSHIP AND MANAGEMENT INSTITUTE 2010, at 187-94 (PLI Corporate Law and Practice, Course Handbook Ser. No. 24318, 2010) (reporting on a two-year strategic planning study involving surveys of legal employers about competencies needed for career success in the law).

45. Richard A. Matasar, The Viability of the Law Degree: Cost, Value and Intrinsic Worth, 96 IOWA L. REV. 1579, 1608 (2011). 
jump into practice without the need to spend significant money on training them. ${ }^{46}$

C. Law Schools' Recent Efforts to Engage Students in Multiple

Opportunities for Learning Skills and Professional Responsibility Across the Curriculum Is Raising the Bar

In response to all of these developments, many law schools across the country have begun to engage in broad-scale curricular reform efforts, while greater numbers of law professors are seeking to develop innovative teaching methodologies and introduce new content into their courses. The exercise discussed in Part IV, infra, is one example of the Authors' attempts at such innovation.

The Carnegie Report notes that, although law schools have increased the number of courses designed to prepare students to practice, such courses are almost always optional rather than mandatory and, as a result, students who opt out will still lack exposure to these critical lawyering skills. ${ }^{47}$ Further, the Carnegie Report highlights certain limitations of the current landscape of legal education, noting a deficiency in fostering the development of ethical and social skills in law students. ${ }^{48}$ By way of recommendation, the Carnegie Report suggests offering a curriculum that integrates the teaching of legal doctrine and analysis, practical skills, and the development of professional identity. ${ }^{49}$ In this sense, it involves another opportunity for legal analysis, a fundamental skill taught during the first year of law school. However, the case method is limited in its ability to help students apply what they have learned to new contexts. Therefore, using a problem method via a simulated case can introduce the skill of problem-solving on behalf of a client. With respect to ethics and professional responsibility, the problem approach helps students understand the interplay of the lawyer's professional responsibilities to a client, the lawyer's obligations as a member of the bar, and the lawyer's own moral standards that may arise within the context of helping a client to solve a legal problem. Presenting students with multiple opportunities to negotiate their

46. Daniel Thies, Rethinking Legal Education in Hard Times: The Recession, Practical Legal Education, and the New Job Market, 59 J. LEGAL EDUC. 598, 599 (2010).

47. See THE CARNEGIE REPORT, supra note 41 , at 87.

48. "Law schools fail to complement the focus on skill in legal analyses with effective support for developing ethical and social skills. Students need opportunities to learn about, reflect on and practice the responsibilities of legal professionals." Id. at 6 .

49. Id. at 13 . 
way through such a complicated maze can better prepare them for the time when they will face these situations as full-time practitioners.

Law schools have begun to raise the bar beyond the baseline mandates and aspirational goals of MacCrate and Carnegie, and are looking seriously at how to implement the suggested methods of Best Practices and/or other innovative models. To bridge the gap, law schools are introducing more experiential opportunities throughout the curriculum that offer students the opportunity to integrate and apply the range of skills and substantive law that they have learned. ${ }^{50}$ Our model offers one such approach to bridging this gap and will help avoid the marginalization of the skills in legal education..$^{51}$

The segregation of courses designed to teach purely doctrinal law, as opposed to lawyering skills or professional responsibility, is destructive, specious, and not in line with practice or pedagogy. The categorization of "pure doctrine" or "pure skills" is a myth in the academy and equally unrealistic in the world of practice. Clients do not walk in with defined labels on their heads that place them into neat doctrinal boxes. Lawyering skills, which are typically siloed into separate courses, must be taught in an interconnected manner in order to model the overlaps and layering of real-world legal issues, particularly those involving ethics. For example, when counseling a client, students must be able to draw upon the substantive and procedural law at issue, as well as problem-solving and communication skills. Similarly, ethical issues arise in messy, unrefined ways throughout different practice areas, often drawing upon doctrinal law and implicating different lawyering skills and styles of representation.

To comply with the ABA Standards as well as the spirit of the MacCrate and Carnegie Reports, law schools must infuse ethics throughout the curriculum, such that the topic has pervasive coverage beginning even in the first year. ${ }^{52}$ Exposure early and often to ethics and professionalism is critical because ethical issues pervade

50. See Robert J. Rhee, On Legal Education and Reform: One View Formed from Diverse Perspectives, 70 MD. L. REV. 310, 334-38 (2011). See generally Larry E. Ribstein, Practicing Theory: Legal Education for the Twenty-First Century, 96 IOWA L. REV. 1649 (2011) (discussing ways that law schools can close the gap between theory and practice to produce more market-ready lawyers).

51. See, e.g., Taylor, supra note 29 , at 251.

52. See generally Rhode, supra note 17 (arguing for a curriculum that addresses professional responsibility both as an individual course and as a pervasive topic across substantive areas). 
all areas of legal practice. ${ }^{53}$ As Professor Russell Pearce notes, "[l]egal ethics is the only subject taught in law school which every student will encounter in practice, regardless of their specialty. ${ }^{154}$ Likewise, ethical issues touch virtually every doctrinal area found in law school and in practice. ${ }^{55}$ Indeed, ethics can serve as a vital connection throughout the curriculum for both students and faculty. ${ }^{56}$ It is insufficient to give students exposure through one required course in law school that primarily focuses on the doctrinal law of professional responsibility and discipline. This focus supports the misconception that ethical issues arise as separate and distinct issues, seemingly divorced from the underlying substantive law. Even if such courses are taught using the problem method, students cannot sufficiently experience how ethical issues are interspersed within other substantive areas and how they might arise in the context of advising a client. Exploring ethical dilemmas in a variety of practice contexts, such as through the use of hypothetical problems and simulated client exercises, exposes students to a broader range of lawyering roles and offers more opportunity for them to practice critical thinking skills in the moment.

Much of the curriculum of law school is focused on teaching students about the outcome of cases that have been litigated and reviewed on appeal. Students are rarely given the opportunity to consider the range of options and issues faced by the attorneys before the case was ever reviewed on appeal or even went to litigation; this is particularly true with respect to the choices the lawyers made in drafting the documents at the heart of a contract litigation. Just as students in a Contracts class will gain a different and arguably deeper understanding of the doctrinal law if they are given opportunities to draft a contract from its origination, students who learn the black letter law of professional responsibility will have a deeper appreciation if they are given an opportunity to frame the issues and apply the relevant law within the context of a practice-oriented situ-

53. "[T]he existing common core of legal education needs to be expanded to provide students substantial experience with practice as well as opportunities to wrestle with the issues of professionalism." THE CARNEGIE REPORT, supra note 41, at 9.

54. See Teaching Ethics, supra note 5, at 735-36.

55. See Rhode, supra note 17 , at $\mathbf{5 0 .}$

56. See Teaching Ethics, supra note 5, at 736.

57. See James E. Moliterno, Legal Education, Experiential Education, and Professional Responsibility, 38 WM. \& MARY L. REV. 71, 100-06 (1996) (discussing why experiential opportunities should be used with teaching professional responsibility). 
ation..$^{58}$ In addition, students must have the chance to consider a broader range of ethical values, beyond the doctrinal law that governs their professional responsibility, in the context of situations likely to arise in practice. Students can recognize that, if they are not given multiple opportunities to consider and deliberate how to resolve ethical issues in a variety of substantive areas, they will be unable to do so effectively when they are in practice. ${ }^{59}$

Thus, the underlying and pervasive messages of both the MacCrate and Carnegie Reports inspired the Authors to craft opportunities for our students to go beyond the case method and to use a problem method via a simulated case to introduce the skill of problem-solving on behalf of a client. The model described in Part IV introduces first-year students to ethical issues within the context of their doctrinal courses, and paves the way for deeper learning in their upper-level required course on professional responsibility, as well as further opportunities to explore ethical issues in practice settings during law school. The model, which draws on the work of proponents of the pervasive method, is designed to encourage law faculty to explore ways to introduce legal ethics and professional responsibility into existing courses through manageable, concrete exercises. ${ }^{60}$ Using exercises like the one explored here will give faculty the chance to "dip a toe" into legal ethics and lawyering skills without the need for considerable outside research and course development. ${ }^{61}$ In addition, we believe that seeking ways to collaborate with colleagues can draw on the expertise of individual faculty members who are already teaching in the field of ethics, rather than

58. See Mary C. Daly et al., Contextualizing Professional Responsibility: A New Curriculum for a New Century, 58 L. \& CONTEMP. PROBS. 193, 193 (1996) ("[C]ontextual courses bring a sense of immediacy and coherence to professional responsibility that too often is missing from the traditional survey courses in which practice and substantive-law settings change from page to page.").

59. See Lauren Solberg, Reforming the Legal Ethics Curriculum: A Comment on Edward Rubin's "What's Wrong with Langdell's Method and What to Do About It," 62 VAND. L. REV. EN BANC 12, 15 (2009); see also Rhode, supra note 17, at 42-43.

60. Compare Daly et al., supra note 58, at 199-211 (describing Fordham's model of offering several contextualized courses on professional responsibility focused on discrete areas of practice), with Rhode, supra note 30, at 142 (describing Stanford's pervasive ethics curriculum, in which time is set aside to cover ethics in first-year courses, students are required to attend special professional responsibility courses, and students must have at least one required, upper-level instruction in ethics).

61. Critics of the pervasive method have voiced concern that it requires enormous cooperation and collaboration among faculty members to develop new components of their course curriculum, as well as development of new expertise in the field of professional responsibility and legal ethics. See Daly et al., supra note 58, at 198 (citations omitted). 
imposing the need for faculty to develop or refine their own expertise in legal ethics. ${ }^{62}$

\section{Law Schools Must Do More to Infuse Opportunities for the Development of Students' Professional Identities}

Teaching students the substantive knowledge of the rules of professional conduct is important, but falls short of the broader goal of shaping the development of our students' professional identities. "Professional identity" encompasses ethical decision-making, professionalism, and social responsibility to ensure access to justice. ${ }^{63}$ The Preamble to the Model Rules of Professional Conduct recognizes the lawyer's multifaceted professional responsibility: "A lawyer, as a member of the legal profession, is a representative of clients, an officer of the legal system, and a public citizen having special responsibility for the quality of justice." ${ }^{16}$ Facilitating the development of our students' professional identity necessarily entails discussion about the purposes and values that should guide the legal profession. Therefore, our curriculum should include not only "understanding and practicing a chosen identity and behavior but, very importantly, a grasp of the social contexts and cultural expectations that shape practice and careers in the law." ${ }^{165}$

Many ethical issues that arise in practice will not be the type that lawyers will have had preexisting experience or conviction with which to resolve. The rules of professional responsibility often force lawyers to negotiate their competing roles as advocates for their clients and officers of the courts. Ethical issues, however, may also challenge lawyers to balance the values of the profession against their own moral values or even those of the community.

Law school, beginning in the first year, is the ideal moment to help students begin to develop a framework for moral and ethical reasoning in the context of practice. ${ }^{66}$ It is naive and unrealistic to

62. A further benefit of this type of faculty collaboration for the students is noted in the Carnegie Report. See THE CARNEGIE REPORT, supra note 41, at 9. "Faculty development programs that consciously aim to increase the faculty's mutual understanding of each other's work are likely to improve students' efforts to make integrated sense of their developing legal competence." Id.

63. Id. at 14 .

64. MODEL RULES OF PROF' L CONDUCT pmbl. (2011).

65. THE CARNEGIE REPORT, supra note 41 , at 31 .

66. See Rhode, supra note 24 , at 196. 
assume that our students only begin to develop their professional identities when they enter the world of practice. In fact, students begin to develop their professional identities from the first day of law school through class discussions, debates with their peers, exposure to public lectures and workshops offered at the law school, and other professional development training. ${ }^{67}$ Some students have entered law school after considerable exposure to the legal profession as legal assistants, paralegals, or even as clients. What students learn in their first year will shape their impressions of what is important (or not important) for the effective practice of law. ${ }^{68}$ Exposure to ethical issues in the first year will give students that much more opportunity to develop a framework for professional decisionmaking across doctrinal areas that includes ethical considerations as part of that professional identity.

By providing exposure to ethical dilemmas prior to any introduction to standards of professional conduct, law professors have a unique opportunity to infuse a discussion of professionalism and ethics, separate from any reference to doctrinal standards of professional responsibility. ${ }^{69}$ While it is critical that students know and understand the application of the rules of professional conduct, it is just as important for them to understand the history and purposes behind them - and to imagine what the legal profession would look like without them. The first year of law school offers an ideal opportunity to engage students in a discussion of lawyers' multiple roles as advisors, advocates, officers of the courts, creators of law, enforcers of law, and members of a just society. This can be accomplished by creative teaching of the first year traditional classes, with a broader lens than just the relevant doctrinal pigeonhole.

In too many cases, law schools focus exclusively on doctrine and analytical skills and ignore the importance of shaping and develop-

67. Elizabeth D. Gee \& James R. Elkins, Resistance to Legal Ethics, 12 J. LeGAL PROF. 29, 34 (1987) (advocating psychological grounds for teaching legal ethics in the first year of law school because it is "a socialization period in which a student's ethical sensitivity and commitment are subject to influence"); see also Rhode, supra note 17, at 51 (commenting that, if legal ethics teaching only occurs after the first year, "many students will be too cynical or preoccupied to give it full attention").

68. See Howard Lesnick, Infinity in a Grain of Sand: The World of Law and Lawyering as Portrayed in the Clinical Teaching Implicit in the Law School Curriculum, 37 UCLA L. REv. 1157, 1159 (1990).

69. There is a lack of consensus about a working definition of "professionalism," as opposed to legal ethics or the standards of professional responsibility. For a useful discussion of the range of ways in which "professionalism" is used, see Roger C. Cramton, On Giving Meaning to "Professionalism," in TEACHING AND LEARNING PROFESSIONALISM: SYMPOSIuM PROCEEDINGS 7, 8 (1996). 
ing students' professional identities. ${ }^{70}$ Even in required professional responsibility courses, professors focus much of their attention on the substantive law of the Model Rules of Professional Conduct and related standards, and have no class time left to explore real-life applications of these rules.

Courses throughout the curriculum offer opportunities to incorporate a broader notion of ethics that encompasses the general nature of moral decision-making by clients, lawyers, and judges. The first year, in particular, is an important time to remind students that they need not retire their moral compass at the doors of the law school and, instead, encourage them to consider the ethical ramifications of the arguments they make in class and the judicial decisions they read. ${ }^{71}$

\section{E. A First-Year Contracts Class Offers Unique Opportunities for Introducing Professional Responsibility and Lawyering Skills}

In the Carnegie Report, the authors urged a more deliberate integration of ethics and professionalism throughout legal education. ${ }^{72}$ The Report noted that "[p]rofessional education is . . . inherently ethical education in the deep and broad sense."73 The exercise described in Part IV embraces that concept and mines the rich history of contract doctrine as a platform on which to overlay the considerations of this "inherently ethical education." ${ }^{\text {"74 }}$ We chose contract law as the base of our first ethics-integration exercise because contract law is a bedrock of transactional practice, and one that is traditionally underserved with respect to the ethical issues replete in such practice. ${ }^{75}$ According to Professor Taylor:

Even early in their first year, law students must grapple with ethical issues underlying doctrinal areas. In a contracts class, for example, such concerns inform discussions about estoppel doctrines, reasonability, unconscionability and

70. See Charlotte S. Alexander, Learning to Be Lawyers: Professional Identity and the Law School Curriculum, 70 MD. L. REV. 465, 465 (2011).

71. See, e.g., Taylor, supra note 29 , at 256-62 (discussing one way to infuse the discussion of ethics into a first-year Contracts course).

72. See THE CARNEGIE REPORT, supra note 41 , at 14

73. Id. at 30 .

74. Id.

75. And from a faculty collaboration point of view, crafting a contracts/ethics fact pattern plays to our primary teaching and writing areas, allowing us to educate each other, while giving us each a new lens through which to view our own teaching and writing. 
countless others. While it is certainly possible to teach these subjects without explicitly acknowledging the importance of ethics, discussions will be richer if that role is called into question directly. ${ }^{76}$

Unfortunately, law schools' professional responsibility courses, as well as the ethics rules and related case law, tend to focus primarily on litigation rather than transactional law. ${ }^{77}$ In many cases, though, transactions are at the very heart of the litigations at issue. As a result, students are typically not given sufficient exposure to ethical issues that tend to arise in transactional practice. ${ }^{78}$ Yet, due to the lack of judicial oversight inherent in transactional practice, exposure to professional responsibilities is all that much more critical.

Some of the ethical issues that transactional lawyers face are universal to all practice settings, though others are more unique. For example, new transactional lawyers may find it challenging to determine how to allocate responsibility between the client and the attorney and who gets to make which decisions. ${ }^{79} \mathrm{~A}$ standard providing that the client will have responsibility for all "business" decisions and the lawyer will have responsibility for "legal" decisions is a clear, concise standard, but one that may not prove practical in the likely event of an issue with both business and legal facets. Under the hypothetical standard, both parties will have responsibility for this issue, which may create conflict. Professional responsibilities owed to third parties in the deal-making process can also pose considerable complications. ${ }^{80}$ Many transactional deals involve representation of multiple parties; therefore, students must understand the parameters and implications of the duty of confidentiality and loyalty owed to clients. ${ }^{81}$ Further, with the increase in interstate and international transactions, students should also understand the multi-jurisdictional considerations of their practice. ${ }^{82}$

Discussion of the ethical implications of transactional practice also provides an excellent opportunity to teach students about the "un-

76. Taylor, supra note 29 , at 251.

77. But see generally DeBORAH L. RHODE, PROFESSIONAL RESPONSIBILITY: ETHICS BY THE PERVASIVE METHOD (1998). Professor Rhode's work includes a number of chapters that offer context-specific material and problems, including ethical issues in contracts and corporate law.

78. Tina L. STARK, DRafting CONTRacts: How and Why LaWyers Do What They Do $377-78$ (2007).

79. Id. at 378-79.

80. Id at $380-81$.

81. Id. at 381 .

82. Id. at 381-82. 
written" law of practice. The rules of professional responsibility leave much to lawyers' discretion, allowing for the development of "norms" of conduct within different practice areas. ${ }^{83}$ Many clinical professors have the opportunity to discuss these issues with students and reflect on those norms within the context of client representation.

Similarly, Professor James Moliterno has pointed out that various areas of professional responsibility rely on "trade usage" or lawyer conduct, separate from the black letter law of professional responsibility. ${ }^{84}$ For example, Model Rule of Professional Conduct 4.1, which is one of the rules implicated in the simulation discussed in Part IV, defines the law governing negotiation conduct. ${ }^{85}$ The Rule does provide a bright line for conduct that would subject the lawyer to discipline, but provides very little information about what is appropriate, ethical conduct in these settings. Therefore, transactional lawyers have developed common understandings of the "rules" of negotiation. ${ }^{86}$

The Authors are certainly not the first to consider highlighting for first-year law students the ethical issues embedded in traditional contract law cases. Professor Celia Taylor believes that "the more frequently ethical concerns confronting lawyers are brought to students' attention and made a focus of discussion, the better we serve our students. ${ }^{177}$ But our approach in crafting a hybrid contracts and professional responsibility exercise is a unique, formalized response to the issue, with benefits for both contracts and ethics faculty members running the exercise that will inform and change their learning and teaching experiences going forward ${ }^{88}$

83. See Jennifer A. Gundlach, "This Is a Courtroom, Not a Classroom": So What Is the Role of the Clinical Supervisor?, 13 CLINICAL L. REV. 279, 290 (2006) (citing Andrea Seielstad, Unwritten Laws and Customs, Local Legal Cultures, and Clinical Legal Education, 6 CLINICAL L. REV. 127, 172 (1999)).

84. See Moliterno, supra note 57, at 102-05.

85. MODEL RULES OF PROF'L CONDUCT R. 4.1 (2011).

86. See Moliterno, supra note 57, at 102-03; James E. Moliterno, Practice Setting as an Organizing Theme for a Law and Ethics of Lawyering Curriculum, 39 WM. \& MARY L. REV. 393, 397 (1998).

87. See Taylor, supra note 29 , at 251 .

88. See infra Part III.B (discussing the benefits of the exercise for students and faculty). 
II. BROADENING THE SCOPE OF LEARNING OBJECTIVES FOR FIRSTYEAR COURSES AND ENSURING ACHIEVEMENT OF THOSE OBJECTIVES: AN ILLUSTRATION

\section{A. Identification of Learning Objectives for a First-Year Contracts Class}

Legal education can be viewed as a continuum in which students enter as novices and move toward becoming experts in the practice of law. ${ }^{89}$ That process involves not only teaching students the substantive law, but also engaging them in the conceptual learning that is so critical to lawyering. As noted in the Carnegie Report, this means "knowing how and when an articulation of the particular meanings and issues in the situation at hand should be in dialogue with conceptual knowledge." ${ }^{\prime 90}$ The more that substantive knowledge is "conditionalized," such that students can begin to identify what knowledge is relevant and why, the closer they move to competency.

In order for this to happen with respect to integrating ethical practice, lawyering skills, and doctrinal knowledge, students need multiple opportunities to not only learn what they can and cannot do under the disciplinary rules, but also what they should and should not do in situations that allow for more ethical discretion. This is best done when students are both introduced to situations that they will face in practice and are given the opportunity to apply the rules and experiment with different options within context-driven situations, while the professor guides their reflective process. ${ }^{91}$ Introducing these types of simulated problems into the classroom can help students understand when, where, and why to use the substantive knowledge they are learning. Moreover, students learn at a deeper level when the material is taught in multiple contexts. ${ }^{92}$

Each phase of legal education, beginning in the first year, plays an important role in the professional development of students. Indeed, much has been written about the need for law schools to identify the desired learning outcomes and "map" the curriculum to ensure that

89. For more on a discussion of learning theory and the movement from novice to expert, see generally NAT'L RESEARCH COUNCIL, How PEOPLE LEARN: BRAIN, Mind, EXPERIENCE, AND SCHOOL (John D. Brandsford et al. eds., 2000) [hereinafter HOW PEOPLE LEARN].

90. THE CARNEGIE REPORT, supra note 41 , at 10.

91. The Carnegie Report calls for teaching practices that "enable learners to take part in the basic features of professional practice itself." $I d$. at 9 .

92. HOW PEOPLE LEARN, supra note 89 , at 62. 
law students have sufficient opportunities to gain the requisite skills and substantive knowledge that they will need before they graduate. ${ }^{93}$ The ABA Section of Legal Education and Admission to the Bar's Standards Review Committee has convened the Student Learning Outcomes Subcommittee, which is undergoing a controversial discussion about imposing outcome measures on law schools. On a micro level, there is also increasing pressure for law professors to consider the specific learning objectives within each of their courses and how best to assess whether students are meeting those objectives.

In our own experience, including informal discussions with colleagues, many law professors who teach first-year courses focus on learning objectives that center on students grasping the core substantive legal rules of the relevant doctrinal field, and the authors are no different in that regard. Indeed, this has traditionally been viewed as the primary focus of the first-year curriculum. Yet, we have also identified a number of additional learning objectives for our students that go well beyond the teaching of substantive legal rules but stem from the application of these doctrinal rules.

For example, we want students to demonstrate that they can effectively communicate these rules of law to their clients. Part of that effective communication involves accurately counseling the client about the legal effect of different courses of action. But students should also be able to demonstrate basic problem-solving skills, such as identifying appropriate solutions and/or courses of action for the client as a result of the legal effect of doctrinal rules. In addition, students should be able to recognize where the language of legal rules is open to interpretation and the types of factual inquiries that will be important for assessing the legal effect of a client's conduct.

Just as important to the substantive law of a first-year course, we want our students to consider the ethical values at play when they counsel their clients with the goal of using the law to solve their clients' problems. For example, we want them to consider what ethical duties they should owe to their clients, as well as whether they should owe any duties to third parties as they propose solutions. We want them to think about the impact of their understanding of the

93. See, e.g., Debra Moss Curtis \& David M. Moss, Curriculum Mapping: Bringing EvidenceBased Frameworks to Legal Education, 34 Nova L. REv. 473, 474-86 (2010); Janet W. Fisher, Putting Students at the Center of Legal Education: How an Emphasis on Outcome Measures in the ABA Standards for Approval of Law Schools Might Transform the Educational Experience of Law Students, 35 S. ILL. U. L. J. 225, 231-42 (2011). 
legal rules on their competency to counsel clients. Students should also gain an appreciation for their role as members of a profession, the impact of their conduct on public perception, and the movement of professional norms of behavior.

Additionally, we aim to introduce our students to the concept that clients' problems often present overlapping and sometimes inconsistent doctrinal issues. Similarly, clients' goals may have both legal and non-legal implications. Therefore, we want our students to demonstrate client-counseling skills in a way that recognizes the interaction of different doctrinal rules and assesses the range of options available for best achieving a client's goals.

Law professors too often struggle over whether it is more important to learn "the basics" of doctrinal law in the first year or to learn to "think like a lawyer." We believe both are critical learning objectives for a first-year course. A student's ability to acquire substantive knowledge of rules is enhanced when those doctrinal rules are connected to meaningful problem-solving activities, especially when teachers help them to "understand why, when, and how those facts and skills are relevant." ${ }^{\prime 4}$ Likewise, any attempt to teach problem-solving skills will inevitably fail without an adequate grounding in the doctrinal law.

Much of what we struggle with as law professors is how to facilitate students' transfer of knowledge to new settings, a skill every lawyer must have in representing clients. Law professors can aid this task by using teaching methods that support a metacognitive approach to learning that focuses on self-assessment and reflection about what worked and what needs improving. Metacognition refers to people's abilities to predict the outcome of a task based on their performance and to monitor their current level of understanding. ${ }^{95}$ For example, students can be challenged during class discussions to consider how a new fact pattern is similar to or different from previous cases discussed, what additional information they need or want to solve a problem, or what alternative arguments can be made. Engaging students in metacognitive practices incorporated into the subject matter the students are learning has been shown to increase the degree to which students transfer their learning to new settings and events. ${ }^{96}$

\footnotetext{
94. HOW PEOPLE LEARN, supra note 89 , at 23.

95. Id. at 12 .

96. Id. at 12,19 .
} 
Waiting until the final exam to test whether our students can successfully transfer what they have learned is too little, too late. Rather, our goal is to introduce multiple methods for assessing the depth and breadth of students' knowledge. Unfortunately, when students know that they will only be required to demonstrate knowledge on the final exam, they often wait too long during the semester to begin to delve into the material at the deeper level necessary to transfer that knowledge to new factual scenarios. Assessment during the semester allows us to get a better grasp of our students' understanding of the material.

By introducing a problem with which students can wrestle in the context of a simulated case, we are able to provide an opportunity for the students to apply what they have learned before the final exam and provide ourselves with an opportunity to assess their understanding of the underlying doctrinal material. At the same time, we are also adding another level of complexity by encouraging students to think beyond the confines of the law that they have learned. Not only do we introduce new doctrinal concepts relating to professional responsibility, but we also offer an opportunity to think about the ethical dimensions of the doctrinal law that they have learned in Contracts. This type of experiential education helps the students to synthesize the law, as well as their relationship to it and the client.

Each year that we teach, we continue to reflect on new ways of thinking about what we want our students to learn and how best to achieve that. As professors, we can and should encourage each other to consider additional opportunities to help students transition into competent practitioners.

\section{B. How We Seek to Meet These Objectives Through Use of a Simulated Exercise in First-Year Contracts}

We set out to develop an exercise designed to give students an opportunity to apply some doctrinal rules of Contracts and practice the additional learning objectives outlined above. We decided this would best be achieved by creating a problem that is presented by a simulated client with whom the students can interact. Therefore, the students would experience a situation that involves counseling a client and negotiating an ethical dilemma arising in that context.

In this exercise, we focused on assessing the students' understanding of the doctrine of fraud. We were drawn to test their understanding of fraud because client fraud in particular creates obvious issues that implicate a lawyer's professional responsibility and 
the skill of client counseling. Because this is a first-year course and students have had neither exposure to any counseling skills nor rules of professional responsibility, the exercise is not designed to assess students' ability to apply lawyering skills or ethical standards. Rather, it is intended to introduce students to some foundational questions and challenges that can arise when they place their doctrinal knowledge within the context of representing a client.

A typical Contracts class will include a unit on the doctrine of fraud. Students who have mastered the concept of fraud in the inducement should be able to understand and apply the appropriate black-letter law. To do this, they need to understand both how the concept of fraud in the inducement works and the effect of a finding of fraud on an otherwise valid contract. They need to be able to identify and articulate when a party's manifestation of assent has been induced by fraud. They should understand on a more concrete level what constitutes a misrepresentation, what makes a misrepresentation fraudulent, what makes a misrepresentation material, what makes those definitions distinct, and why those distinctions matter. Students should also understand what makes a contract void or voidable by either or both parties.

In order to assess the students' understanding of these doctrinal concepts, the factual scenario involves a client who engaged in fraudulent behavior in connection with the signing of a contract. Specifically, she misrepresented personal information upon which the other contracting party relied when entering into the contract that is material to the terms of the contract. In order to effectively counsel their client, the students will need to demonstrate their understanding of the doctrine of fraud and its application to this scenario. It provides a discrete fact pattern for synthesizing the law that they have learned with new facts, another critical lawyering skill.

As noted above, we wanted to create an ethical dilemma that would be obvious enough to even a layperson and that would require the students to make some decisions about the ethically appropriate choice or choices of action. From this, we wanted to engage the students in a discussion about what ethical standards they would want to have in place and why, as well as to whom they should owe a duty of professional responsibility. Therefore, we decided that it should become apparent to the student during the course of the exercise that the client has engaged in misrepresentation in connection with the contract that the attorney is negotiating on her behalf and about which the other contracting party has no knowledge. 
We also decided that this was a good opportunity to introduce students to some of the Model Rules of Professional Responsibility that are relevant to the scenario, but not before they are given a chance to think about what they would want those rules to say if they were to draft them for themselves. Therefore, we wanted to include time in the discussion of the exercise to generate their ideas about how to construct the standards for ethical conduct that should govern a lawyer confronted with this situation. Because the students have had no formal introduction to the Model Rules, we decided to ask them to craft the wording of a rule. Only after they have drafted a rule do we then show them the actual wording of the relevant rule. This provides further support for students' understanding of statutory construction and legislative drafting.

Finally, we wanted to prompt the students to think about some of the challenges that can arise when seeking solutions to clients' problems and counseling clients about their options. For example, we want the students to consider how an attorney might conduct herself when she disapproves or disagrees with a client's past or intended conduct. In addition, students should be asked to think about the level of competency that they should have in the substantive law to counsel a client effectively. As they discuss options with the client, students will also struggle with how to make the law accessible and understandable for the client to make an informed decision.

To introduce our students to the concept that clients' problems often present overlapping doctrinal issues, we wanted to create a scenario where the doctrinal laws of professional responsibility and contract law carry implications both for the lawyer and the client. In the exercise, the students will need to consider the legal rules that they must follow to avoid discipline as well as potential liability as partners in the fraud. The Model Rules of Professional Responsibility draw upon the doctrine of fraud in the establishment of the relevant standards.

\section{THE SIMULATION}

\section{A. Overview of the Exercise}

Our ideal approach for this exercise is to provide the students with the instruction memorandum in Appendix A before class, so they will have a basic understanding of how the simulation will work. Each student is also given the memorandum from a senior 
partner at the firm that relays background information about a new client for the law firm in Appendix B.

The initial part of the class session is devoted to the client meeting, which can take several forms depending on the class size and time available. Ideally, we break the students into law firm groups of no more than five students before the session. Each law firm group has fifteen to twenty minutes to meet with its new client to prepare for the client's meeting with Fox later that week. The person playing the role of the client has been given the additional facts set out in Appendix $\mathrm{C}$. The client meeting can also be done with one law firm group and one client, with the meeting played out in front of the rest of the class - "fish bowl" style. During the meeting, the law firm group has the opportunity to learn new facts from the client and must then counsel the client about how to proceed with the upcoming contract negotiation and how to resolve the embedded ethical issues.

From the senior partner memorandum set out in Appendix B, the students "meet" their new client Lacy, who is on the cusp of singing stardom. She is a finalist on American Idol and needs legal representation to assist her in negotiating a recording contract with Fox. The rules and regulations for the show are clearly set out on the show's website. When applying to be on the show, Lacy has made certain required representations about herself. These representations are repeated in the form contract Fox is asking her to sign in the "recital section." The person playing the role of Lacy has knowledge of certain additional facts (Appendix C) and has been instructed to hint about these facts in an effort to get the students to uncover the facts that create the underlying ethical and legal issue. In essence, Lacy is committing fraud, and, once the students uncover this, she is eager to have the lawyers assist or at least not reveal her fraud.

After the session with the client, the class then comes together for a plenary discussion on its experience with the foundational lawyering skills of client interviewing and counseling, problem solving, and synthesis of law and fact. We ask one person from each group to report on the session and to describe the outcome and any next steps discussed. Some sample discussion points are set out in Appendix D. Part of this process involves soliciting from the group a review of the doctrinal law and its implications for this client situation. As facilitators, we help move the group discussion along not just by framing the theory of the client's case, but also by teasing out of the student groups the ethical situation the lawyers are facing and how they feel about it. They will often frame the issue as the "cli- 
ent's problem," and then, with further probing, realize that it is, in fact, their problem. We keep the conversation grounded, initially, in black-letter contract law. This is a foundational level where they will likely be most comfortable (i.e., identifying the applicable doctrine of contract law).

Once they have that sorted out, we then move to the recognition that the lawyer also faces "a problem." The students should think about ways to solve the problems, both separately and in relation to one another. This can offer an opportunity for them to consider their own fiduciary and professional obligations to the client, as well as their obligations to third parties and to the profession. This helps develop the lawyering skills of identifying a "theory of the case" and problem solving.

Next, we gently guide them, if they need it, to identify the relevant ethical issues in the exercise. We then seek feedback from the group on how to resolve them, in keeping with the client's goal. If a conflict appears (and one usually does), we facilitate brainstorming on how to resolve the conflict. Students need to talk through the next steps they would take, walking through how they would approach their proposed solution with the opposing counsel. Then we engage in a group drafting exercise of one or more ethical rules that arise from the client's situation. What should the relevant ethical standard for lawyers look like and why? Once we have a consensus on what the language should look like, we conclude this exercise with an introduction to, and examination of, the relevant Model Rules of Professional Conduct. The students experience a true "Aha!" moment when they see how closely the rules they drafted are to the actual rules.

\section{B. Benefits of the Exercise}

In addition to the myriad benefits discussed above, an exercise like ours has additional benefits for both students and faculty. Despite the fact that much legal (and nonlegal) work involves a considerable amount of collaboration, most law school classrooms offer few opportunities for students to work together in a group to solve a problem. Indeed, law schools have been criticized for this by a number of commentators. ${ }^{97}$ Business schools, on the other hand,

97. See, e.8., Robert J. Rhee, Follow the M.B.A. Model, 29 NAT'L L.J. 22, 22 (2007) ("Law schools can do a better job of incorporating group work, case-study analysis and experientiallearning methods into the structural fabric of the curriculum."); Clifford S. Zimmerman, "Thinking Beyond My Own Interpretation": Reflections on Collaborative and Cooperative Learning 
have long used group work on case studies as an effective pedagogical tool. ${ }^{98}$ Increasing student opportunities for collaborative work will help flesh out their skill set to better prepare them for the practice of law, which is typically not a solitary exercise. ${ }^{99}$

Additionally, integrating doctrine and skills will reinforce our students' comprehensive understanding of the underlying doctrinal law, while further developing their professional identities. An exercise like our simulation will arguably make the age-old doctrine of fraud seem more relevant to the students.

This project has offered the Authors the opportunity to collaborate on crafting the exercise and supporting materials, as well as to work together on various presentations about exercises like this idea and, of course, on this Article. ${ }^{100}$ As a result of that collaboration, we have each gained a renewed appreciation for, and understanding of, areas of law outside our own teaching and writing spheres. Even more salient, we have each gained a deeper appreciation for our own areas of expertise, by seeing them through a new lens. As we continue to develop exercises like the one described in this Article, we hope to deepen our awareness of the layers and complexities in our own areas of expertise, and to reach out to colleagues for new alliances and collaborations. On a macro level, engaging in collaborations such as these may foster exposure to, or at least review of, new doctrinal areas. This may trigger renewed interest and engagement in teaching familiar material, as well as the development of new teaching skills and ways to present material to reach a broader array of students with a variety of learning styles.

\section{CONCLUSION: MEASURES OF SUCCESS AND NEXT STEPS}

An exercise like this one poses certain challenges, one of which is how to assess the merits of introducing this type of exercise into the

Theory in the Law School Curriculum, 31 ARIZ. ST. L.J. 957, 965 (1999) ("[L]egal education, as an institution, is not receptive to the use of collaborative or cooperative learning teaching pedagogies.").

98. See Elizabeth A. Reilly, Deposing the "Tyranny of Extroverts" Collaborative Learning in the Traditional Classroom Format, 50 J. LEGAL EDUC. 593, 604 (2000) (observing that collaborative learning is common in business schools).

99. See Cassandra L. Hill, Peer Editing: A Comprehensive Pedagogical Approach to Maximize Assessment Opportunities, Integrate Collaborative Learning, and Achieve Desired Outcomes, 11 NEV. L.J. 667, 669-70 (2011).

100. We first presented the concept at the Sixth International Conference on Contracts at Stetson College of Law in February 2011 and then again at the Institute for Law Teaching and Learning Conference at New York Law School in June 2011. 
first-year curriculum. While we have identified core-learning outcomes in connection with this type of exercise, the next step is to determine the impact that it has on our students' educational experiences and professional development. Part of this involves the creation of one or more assessment tools (beyond a final exam) to determine whether students have reached these learning goals. We have considered how we might administer an objective assessment following the exercise that would take place within the first-year course. In addition, we have explored the idea of determining whether we can assess any long-term impact on students' performance in their upper-level courses. Finally, we have created an evaluation form for students to provide their subjective feedback about the impact of the exercise on these learning goals. We hope to engage in a thoughtful assessment study that will give us further evidence about the value of these types of exercises and look forward to this next research project.

We are mindful that there are those in the Academy who will push back on any deviation from traditional, Socratic classroom learning. We are also aware that our students may be reluctant to broaden the scope of the class material or will be concerned that being asked to view contract law through the lens of ethics may obfuscate their understanding of the underlying contract law. Arguably, just the opposite is true. For those willing to try, bridging the gap between doctrine and skills may, in fact, begin to eliminate that gap and help refocus both students and faculty on the synergies and overlaps between and among ethics and other areas of law. 


\title{
APPENDIX A: INSTRUCTION MEMORANDUM FROM FACULTY TO STUDENTS
}

\section{MEMORANDUM}

\author{
TO: $\quad$ Contracts Students \\ FROM: Professor \\ RE: $\quad$ Contracts Simulation Exercise \\ DATE:
}

For our next class, please read the "Memorandum from Senior Partner" in the "Handouts" tab on TWEN.

You are assigned to Law Firm Group \# _ and will work with your fellow group members on the exercise during your meeting with your new client. You will have fifteen minutes with your client and then we will come together to hear reports from each group on its client session. In the process, we will begin teasing out the ethical issues layered in this seemingly straight-forward contract negotiation.

Think about what questions you might want to ask Lacy in the client meeting. I am delighted to note that this is also a chance to review substantive contract law, to frame ethical issues, and also to work on the skill of client counseling.

Thanks - see you at our next class. 


\title{
APPENDIX B: ASSIGNMENT MEMORANDUM to Be Distributed to STUDENTS
}

\section{MEMORANDUM}

\author{
TO: $\quad$ Student \\ FROM: Senior Partner \\ RE: $\quad$ New Client: Lacy Lowenstein \\ DATE:
}

I met with our new client, Lacy Lowenstein, today and here is what I learned.

Lacy has dreamed of being a star since she was a little girl. She was the lead in every school musical and managed to fit in some school work, but her real focus was developing herself into a true triple threat: singing, dancing, and acting.

Her parents were very supportive conceptually, but, sadly, could not be of much support financially. So she worked any job she could to raise the cash for her myriad lessons. She sang at so many family weddings that non-family members started hiring her to sing at their events. That was good money, but not terribly reliable. She applied for any and all jobs, but her blessing and her curse was that she had a true baby face-she always looked at least ten years younger than her true age. According to Lacy, this is a delightful fact in one's thirties - not so much in one's twenties!

Lacy is now sure she is on the cusp of her big break. Through the years she has watched with interest how American Idol has become a national phenomenon. She had never auditioned before - she sheepishly told me that she had been on a few dates with Simon Cowell back before he hit it big, and things did not end well. He told her he did not want to see her again, and that he wasn't being rude, he was just being honest. Being with her, he said, was like being trapped on a cruise ship from Bayonne to Budapest. She did not understand this metaphor, which, like most of his metaphors, made little sense.

When she saw he was leaving American Idol, she knew this was her moment. She eagerly pored over the Rule and Regulations section of its website, and got the feeling that she always got when 
something good was about to happen. The rules required that she be able to prove that:

(1) At the time of registration and audition, she was a U.S. Citizen;

(2) She never progressed in a previous season of $A I$ to the top thirty;

(3) She had no contract for talent representation or a music recording contract; and

(4) She was sixteen to twenty-eight years old on January 1 , 2011 (which means she must have been born on or between January 1, 1983 and January 1, 1995). If she was born before or after this window, she is not eligible to participate this season.

After confirming that Simon was not involved in the show at all, Lacy completed, signed, and submitted the application. Much to her horror, the only audition site left was in Pierre, South Dakota and that was a very long bus ride. Thankfully, she sailed through the first round and got her golden ticket to Hollywood. During the audition, she charmed the judges with her a capella version of a mash of "Proud Mary" and "Thriller," and tried not to flinch when Randy Jackson said, "Man, Dawg, I wish Cowell was here-he would really dig you." She was somewhat gratified when Steven Tyler replied, "But I dig you!"

Lacy is now one of the top ten finalists and the producers want her to sign their standard form talent contract. She wants us to represent her in this matter and I've scheduled a meeting for you two tomorrow.

I've set up a client file and, as we do for all of our new clients, I've run a background check on Lacy and it's clean.

I've reviewed the form of contract with Fox and it is pretty standard. As you will see, the agreement has in its "recital section" a reference to the application form, and the agreement contains a number of representations to be made by our client, restating her compliance with the Rules and Regulations regarding her age, country of citizenship, and lack of professional representation as an artist. Fox is eager to get this contract signed so that she can appear in the 
finalist round, which begins next week. Lacy is set to sign the contract at its offices on Friday at 10 AM. 


\section{APPENDIX C: ADDITIONAL FACTS FOR CLIENT "LACY LOW- ENSTEIN" \\ Instructions for Lacy Lowenstein}

You will be attending a follow-up meeting with junior associates from the law firm that represents you in your negotiations with Fox as a finalist on American Idol. Please review the attached memorandum, which includes background information about your story.

In this upcoming meeting with your lawyers, please begin by asking about the results of the background check that you permitted the law firm to do. Once the lawyer says the background check is "clean," you should be visibly relieved, so much so that they should ask you why you are so relieved. The point is that you make every effort to prompt them to ask.

If and only if you are asked about why you are so relieved, you should disclose that you have been lying about your age for years, and now it seems that your "permanent record" has been "corrected" to reflect that your age is twenty-one. You should then tell the attorney that your actual age is thirty-one years young. Once you started on your road to stardom, you have never told anyone your real age and have lied about it for so long you almost believed it yourself. In fact, you have a driver's license that has your real name, real address, and real social security number, but a birth year of 1990 instead of your actual birth year of 1980. You know a guy who knows a guy who took care of it. Enough said.

After explaining all of this, you should forbid your lawyer from disclosing any of this information in connection with the signing of the contract with American Idol. 


\section{APPENDIX D: DISCUSSION POINTS FOR PLENARY SESSION}

\section{Black-Letter Contract Law - Fraud in the Inducement}

Lacy has made two affirmative misrepresentations under section 159 of the Restatement (Second) of Contracts by making an assertion not in accordance with the facts: (1) when she filled out the application, and (2) when she signed the contract. ${ }^{101}$

This misrepresentation is fraudulent under section 162(1)(a) since she knows her true birthday and therefore has made this assertion knowing it is not in accord with the facts. ${ }^{102}$

This misrepresentation is also material under section 162(1)(b) because Lacy knows her representation about her age is likely to induce Fox to enter into the contract with her. ${ }^{103}$

Bottom Line: Because Fox's manifestation of assent was induced by her fraudulent and material misrepresentation, on which they are justified in relying, the contract is voidable by Fox.

As a practical, real-world matter, Fox can only sue her to void the contract if and when they learn of the misrepresentation. So the contract is voidable, but they don't know it. Yet. Its background check will likely come back clean, so the only way it will find out about the misrepresentation is through you. Which leads us to ....

\section{The Model Rules of Professional Conduct}

Model Rule of Professional Conduct 1.2(a) requires the lawyer to abide by a client's decisions concerning the objectives of representation and consult with the client as to the means by which they are pursued.$^{104}$ Comment 1 clarifies that the client has "ultimate authority" to decide purposes served by legal representation, "within the limits imposed by law and the lawyer's professional obligations." 105 Rule 1.2(d) further prohibits a lawyer from counseling a client to engage

101. Restatement (SECOND) OF CONTRACTS $\$ 159$ (1981).

102. Id. $\S 162(1)(\mathrm{a})$.

103. Id. \$162(1)(b).

104. MODEL RULES OF PROF' L CONDUCT R. 1.2(a) (2002).

105. Id. at R. $1.2 \mathrm{cmt}$. [1] (emphasis added). 
in fraud or assisting a client in conduct that the lawyer knows is criminal or fraudulent. ${ }^{106}$

Rule 1.4 requires the lawyer to explain the matter to the extent necessary for the client to make informed decisions. ${ }^{107}$

Rule 1.6 prohibits a lawyer from revealing confidential information (any information that relates to the representation of the client) unless the client gives informed consent or if the lawyer reasonably believes that she has to reveal the information to prevent the client from committing a crime or fraud that is reasonably certain to result in substantial injury to the financial interests or property of another and in furtherance of which the client has used or is using the lawyer's services. ${ }^{108}$

Rule 4.1 prohibits a lawyer from knowingly making false statements of material fact and failing to disclose material facts when disclosure is necessary to avoid assisting crime or fraud by a client, unless disclosure is prohibited by Rule 1.6. ${ }^{109}$ Misrepresentation can occur when a lawyer knowingly incorporates a false statement of another person, affirms a false statement of another person, or makes a partially true but misleading statement or omission that is the equivalent of an affirmative false statement. ${ }^{110}$

Bottom Line: The attorney is going to be forced to disclose the fraud if she continues to represent Lacy in the negotiations and/or had any involvement in any documents that have been provided to Fox by the law firm. Even if the attorney withdraws, she may be permitted to disclose the information to Fox pursuant to Rule 1.6(b).

\section{Problem Solving Suggestions}

Lawyer must counsel the client about the implications of fraud/lawyer assisting the client's fraud.

Client/lawyer can disclose the misrepresentation/seek a waiver of the age limit.

\footnotetext{
106. Id. at R. 1.2(d).

107. Id. at R. 1.4(b)

108. Id. at R. 1.6.

109. Id. at R. 4.1.

110. Id. at R. $4.1 \mathrm{cmt}$. [1].
} 
Client can withdraw from the competition/seek non-disclosure agreement from Fox.

Lawyer can withdraw from the representation, but may still be permitted to disclose.

Client can spin the earth backwards (à la Superman) and become younger.

\section{Other Points to Consider, if Time Permits}

What if our background check on Lacy revealed her true age (rather than learning about it from the client)? Same result?

What if Lacy were only two weeks older than the age cut-off (arguably reducing the potential financial injury for Fox)? Same result?

What if Lacy were within the required age range, but when interviewed for the background clips that are used during the competition, Lacy lied and said that she had been abandoned by her parents and was homeless, living in her car? In reality, she spent a lot of time in her car, which happened to be a brand new Porche, parked in her parents' estate in East Hampton, making out with her boyfriend. Same result?

What if Lacy were instead one year younger than the minimum age required (making the contract voidable on her part as a minor)? Same result? 